\title{
Effect of dietary protein level on lipid deposition in broilers during the finishing period
}

\author{
ML Grisoni 1", M Larbier 1, G Uzu 2, PA Geraert 1 \\ 1 INRA Station de Recherches Avicoles, 37380 Nouzilly; \\ 2 Rhône-Poulenc Animal Nutrition, 03600 Commentry, France
}

(Received 26 March 1990; accepted 20 July 1990)

\begin{abstract}
Summary - Male and female broilers were fed from 3 wk of age with one of 2 experimental diets containing 20 or $23 \%$ of crude protein and $3170 \mathrm{kcal}$ metabolisable energy (ME)/kg. Twenty-five birds per treatment were slaughtered at 5 or $7 \mathrm{wk}$ of age to study the influence of dietary protein concentration on lipid deposition both in abdominal cavity and in the rest of the carcass. Though the higher protein diet did not modify the weight gain, it improved the feed conversion and reduced the fattening of birds. This effect was obtained 2 wk after experimental food distribution. The reduction in fattening was more pronounced in females than in males using abdominal fat ratio as a criterion. On the other hand, the lipid proportion in the rest of the carcass was more reduced in males than in females when birds were fed $23 \%$ protein ( 11.3 versus $7.7 \%$ at 7 wk of age). Linear regression equations between abdominal fat and lipid content in the carcass confirmed that the decreasing of lipid content obtained with a higher protein concentration in the diet depended on the adipose compartment and on the sex of broilers. The carcass lipid content cannot be determined accurately from abdominal fat alone and is consistently affected by the composition of the diet.
\end{abstract}

dietary protein / abdominal fat / body lipid / broiler

Résumé - Influence de l'apport alimentaire de protéines sur le dépôt de lipides chez le poulet de chair en période de finition. Des poulets mâles et femelles sont nourris à partir de l'âge de 3 semaines avec l'un des 2 régimes expérimentaux isoénergétiques $(3170 \mathrm{kcal}$ d'énergie métabolisable (EM) $/ \mathrm{kg}$ ) et titrant 20 ou 23\% de protéines. A l'âge de 5 ou de 7 semaines, 25 animaux par traitement sont abattus afin d'étudier l'influence de l'apport alimentaire de protéines en période de finition sur le dépót de lipides dans la cavité abdominale et le reste de la carcasse. Un apport supérieur de protéines dans l'aliment conduit à une réduction de l'indice de consommation et de l'engraissement des animaux sans affecter le gain de poids. Cet effet est obtenu après 2 semaines de distribution de l'aliment expérimental. Toutefois, la proportion de gras abdominal est plus fortement réduite chez les femelles que chez les mâles tandis qu'au contraire, celle des lipides de la carcasse diminue de façon plus importante chez les mâles que chez les femelles $(11,3$ contre $7,7 \%$ à l'âge de 7 semaines). Le calcul des équations de régression linéaire entre la quantité de lipides dans la cavité abdominale et celle du reste de la carcasse confirme que la réduction de l'engraissement après distribution d'un aliment riche en protéines dépend du compartiment lipidique considéré et du sexe des animaux. II n'est alors pas possible de déterminer avec précision la quantité de lipides dans la carcasse éviscérée à partir seulement du gras abdominal et sans tenir compte de la composition du régime alimentaire.

protéines alimentalres / gras abdominal / lipide corporel / poulet de chair

\footnotetext{
${ }^{*}$ Correspondence and reprints
} 


\section{INTRODUCTION}

A major problem that concerns the poultry industry is the quantity of fat deposited in broiler carcasses. Indeed, abdominal fat is a source of loss during preparation of poultry cuts (Summers and Leeson, 1979; Fisher, 1984).

Abdominal fat pad is a useful indicator of body fatness. Delpech and Ricard (1965) showed a high correlation between abdominal fat and lipid content in broilers. Recently, Scheele et al (1981) showed that the main factors affecting total fat content are not necessarily identical to factors responsible for abdominal fat accumulation. Decrease in the total body lipid content or abdominal fat was often observed when dietary protein concentration was increased (Guillaume and Summers, 1970;
Pfaff and Austic, 1976; Waldroup et al, 1980; Pesti and Fletcher, 1984).

The present study was conducted to compare the effect of dietary protein concentration on lipid deposition in both the abdominal cavity and the rest of the carcass, of male and female birds at 5 or 7 wk of age.

\section{MATERIALS AND METHODS}

Four hundred and eighty 1-d-old Shaver chickens were allotted to 8 floor pens. Males and females were reared separately; they were wingbanded at $1 \mathrm{~d}$ of age allowing individual identification. Until $21 \mathrm{~d}$ of age, a starter diet containing $23 \%$ crude protein (CP) and $3170 \mathrm{kcal}(\mathrm{ME}) / \mathrm{kg}$ was distributed (table I). From $22 \mathrm{~d}$ of age, half the birds received an experimental diet containing $20 \% \mathrm{CP}$ and $3170 \mathrm{kcal}(\mathrm{ME}) / \mathrm{kg}$, while the other half was fed the starter diet (table I). Both

Table I. Composition (\%) and analysis of the diets.

\begin{tabular}{lcc}
\hline & $\begin{array}{c}\text { Starter and } \\
\text { high protein grower }\end{array}$ & $\begin{array}{c}\text { Low protein } \\
\text { grower }\end{array}$ \\
& & \\
\hline Ingredients & 55.1 & 62.9 \\
Maize & 35.2 & 27.3 \\
Soybean meal & 5.5 & - \\
Maize oil & - & 5.5 \\
Tallow & 0.15 & 0.15 \\
DL-methionine & 0.4 & 0.4 \\
Salt & 1.15 & 1.22 \\
Calcium carbonate & 1.87 & 1.90 \\
Dicalcium phosphate & 0.50 & 0.50 \\
Vitamins & 0.15 & 0.15 \\
Trace minerals ${ }^{1}$ & & \\
Analysis & & 3170 \\
Calculated ME (kcal/kg) & 3170 & 19.95 \\
Measured protein (\%) & 22.85 & 0.77 \\
Calculated sulphur AA (\%) & 0.85 & 1.02 \\
Measured lysine (\%) & 1.24 & 0.71 \\
Measured threonine (\%) & 0.80 & 1 \\
Calculated calcium & 1 & 0.4 \\
Calculated available phosphorus & 0.4 & \\
\hline
\end{tabular}

1 Larbier and Leclercq (1980). 
diets were pelleted and fed ad libitum. Each experimental group consisted of 4 replicates of 60 birds ( $2 \times 2$ sexes).

At 35 and $49 \mathrm{~d}$ of age, weight gains and feed intakes were recorded. At each age, after an overnight fast the birds were fed again for $1 \mathrm{~d}$ and then 25 broilers from 4 pens (2 diets $\times 2$ sexes) were exsanguinated and plucked. The animals slaughtered were a representative sample of the population of each pen.

The carcasses were cooled at $4^{\circ} \mathrm{C}$ overnight. The abdominal fat was then excised and weighed. Each carcass (without head, neck, wing and leg extremities, abdominal fat and viscera) was weighed, homogenized (Robot Coupe $\mathrm{SA}$, France) and a sample was freeze-dried. $\mathrm{Ce}-$ lite (sillicium oxide) was added before grinding to prevent lipid loss. Freeze-dried samples were next reground in a blender before fat analysis. Lipid content was determined in a Soxhlet apparatus with diethyl ether.

Analysis of variance was used to analyse the effect of CP during the finishing period on carcass composition. The abdominal fat was expressed in absolute amounts proportional to live weight and to carcass weight. The same calculations were made for carcass lipids. Finally, the correlation between abdominal fat and carcass lipids were calculated for both sex and dietary treatments according to the linear regression procedure. The total carcass lipids were calculated according to the sum of carcass and abdominal lipids using the formula:

Abdominal lipids $=$ abdominal fat pad $\times 0.88$ (unpublished results).

\section{RESULTS}

Growth performance of the chickens is shown in table II. Weight gain was not affected by dietary protein content at the age of 5 and 7 wk. However, male and female birds presented a marked sexual dimorphism which became more pronounced with age. Though increasing the protein concentration did not influence the body weight at 5 or 7 wk, it improved feed conversion: for the 3-5-wk period, 1.75 versus 1.84 with 23 and $20 \%$ CP respectively. But this difference decreased with age; for the 3-7-wk period, the variation became $2 \%$.

Tables III and IV show the body composition at 5 and 7 wk of age, respectively. The higher dietary protein level reduced lipid content both in the abdominal cavity and in eviscerated carcasses, except for the 5-wk-old females. When the various lipid deposits were considered as a proportion of carcass weight (fig 1 and fig 2 for birds at 5 and 7 wk of age, respectiveiy), the reduction in fatness appeared significant already at 5 wk of age ie after 2 wk of experimental feeding.

However, the effect of dietary protein concentration on abdominal fat ratio in carcasses appeared higher for the females than for males at 7 wk of age. This ratio

Table II. Influence of dietary protein level on growth performances of chicks between 3-5 or 3-7 wk of age.

\begin{tabular}{|c|c|c|c|c|}
\hline $\begin{array}{l}\text { 3-5 wk period: } \\
\text { Dietary protein level }\end{array}$ & & & & \\
\hline Sex & M & $\mathrm{F}$ & M & $F$ \\
\hline Weight gain (g) & $820 \pm 10$ & $669 \pm 8$ & $845 \pm 9$ & $670 \pm 7$ \\
\hline Feed conversion rate & & & & \\
\hline 3-7 wk period: & & & & \\
\hline Dietary protein level (\%) & & & & \\
\hline Sex & $M$ & $F$ & $M$ & $F$ \\
\hline Weight gain (g) & $1763 \pm 19$ & $1404 \pm 17$ & $1786 \pm 20$ & $1397 \pm 15$ \\
\hline Feed conversion rate & & & & \\
\hline
\end{tabular}


Table III. Influence of dietary protein level on body composition of 5-week-old chickens ${ }^{1}$.

\begin{tabular}{|c|c|c|c|c|c|c|}
\hline \multirow{2}{*}{$\begin{array}{c}\text { Sex } \\
\text { Dietary protein cont }\end{array}$} & \multicolumn{2}{|c|}{ Males } & \multicolumn{2}{|c|}{ Females } & \multicolumn{2}{|c|}{ ANOVA ${ }^{2}$} \\
\hline & 20 & 23 & 20 & 23 & Effect of diet & Effect of sex \\
\hline Live weight $(\mathrm{g})$ & $\begin{array}{r}1289 \\
\pm \quad 22\end{array}$ & $\begin{array}{r}1318 \\
\pm \quad 23\end{array}$ & $\begin{array}{r}1108 \\
\pm \quad 19\end{array}$ & $\begin{array}{r}1182 \\
\pm \quad 14\end{array}$ & * & $\star * \star *$ \\
\hline Carcass weight $(\mathrm{g})$ & $\begin{array}{r}967 \\
\pm \quad 19\end{array}$ & $\begin{array}{r}1002 \\
\pm \quad 20\end{array}$ & $\begin{array}{r}800 \\
\pm \quad 18\end{array}$ & $\begin{array}{r}866 \\
\pm \quad 13\end{array}$ & ** & $\star * * *$ \\
\hline Abominal fat $(g)$ & $\begin{array}{r}38.4 \\
\pm \quad 1.4\end{array}$ & $\begin{array}{r}29.9 \\
\pm \quad 1.4\end{array}$ & $\begin{array}{r}34.7 \\
\pm \quad 1.9\end{array}$ & $\begin{array}{r}29.9 \\
\pm \quad 1.3\end{array}$ & $\star \star \star \star$ & NS \\
\hline Carcass lipids (g) & $\begin{array}{r}160 \\
\pm \quad 4.5\end{array}$ & $\begin{array}{r}149 \\
\pm \quad 5.0\end{array}$ & $\begin{array}{r}134 \\
\pm \quad 4.4\end{array}$ & $\begin{array}{r}135 \\
\pm \quad 4.5\end{array}$ & NS & $* * *$ \\
\hline Total lipids (g) & $\begin{array}{r}194 \\
\pm \quad 5.4\end{array}$ & $\begin{array}{r}175 \\
+\quad 5.9\end{array}$ & $\begin{array}{r}164 \\
\pm \quad 5.8\end{array}$ & $\begin{array}{r}161 \\
\pm \quad 5.2\end{array}$ & NS & $\star * \star *$ \\
\hline
\end{tabular}

${ }^{1}$ Mean $\pm \mathrm{SEM} ; 25$ animals per treatment. ${ }^{2}$ Analysis of variance: ${ }^{\star} P<0.05 ;{ }^{* \star} P<0.01 ;{ }^{* * *} P<0.001$; NS: non significant. For every variable, the diet $x$ sex interaction was non significant.

Table IV. Influence of dietary protein level on body composition of 7-wk-old chickens ${ }^{1}$.

\begin{tabular}{|c|c|c|c|c|c|c|}
\hline \multirow{2}{*}{$\begin{array}{l}\text { Sex } \\
\text { Dietary protein content (\%) }\end{array}$} & \multicolumn{2}{|c|}{ Males } & \multicolumn{2}{|c|}{ Females } & \multicolumn{2}{|c|}{ ANOVA2 } \\
\hline & 20 & 23 & 20 & 23 & Effect of diet & Effect of sex \\
\hline Live weight (g) & $\begin{array}{r}2199 \\
\pm \quad 22\end{array}$ & $\begin{array}{r}2222 \\
\pm \quad 22\end{array}$ & $\begin{array}{r}1840 \\
+\quad 24\end{array}$ & $\begin{array}{r}1833 \\
+\quad 21\end{array}$ & NS & $\star \star \star *$ \\
\hline Carcass weight (g) & $\begin{array}{r}1616 \\
+\quad 21\end{array}$ & $\begin{array}{r}1636 \\
+\quad 17\end{array}$ & $\begin{array}{r}1321 \\
+\quad 17\end{array}$ & $\begin{array}{r}1309 \\
+\quad 17\end{array}$ & NS & $\star * \star *$ \\
\hline Abdominal fat (g) & $\begin{array}{r}65.7 \\
+\quad 3.4\end{array}$ & $\begin{array}{r}61.4 \\
+\quad 2.7\end{array}$ & $\begin{array}{r}68.4 \\
+\quad 3.7\end{array}$ & $\begin{array}{r}58.4 \\
+\quad 3.9\end{array}$ & * & NS \\
\hline Carcass lipids (g) & $\begin{array}{r}273 \\
+\quad 10\end{array}$ & $\begin{array}{r}244 \\
\pm \quad 6\end{array}$ & $\begin{array}{r}239 \\
+\quad 8\end{array}$ & $\begin{array}{r}219 \\
+\quad 8\end{array}$ & ** & $\star \star *$ \\
\hline Total lipids (g) & $\begin{array}{r}331 \\
\pm \quad 12\end{array}$ & $\begin{array}{r}298 \\
\pm \quad 8\end{array}$ & $\begin{array}{r}300 \\
\pm \quad 11\end{array}$ & $\begin{array}{r}270 \\
\pm \quad 11\end{array}$ & $* *$ & ** \\
\hline
\end{tabular}

1 Mean \pm SEM; 25 animals per treatment. ${ }^{2}$ Analysis of variance: ${ }^{*} P<0.05 ;^{* *} P<0.01 ;{ }^{* * *} P<0.001$; NS: non significant. For every variable, the diet $x$, sex interaction was non significant. 


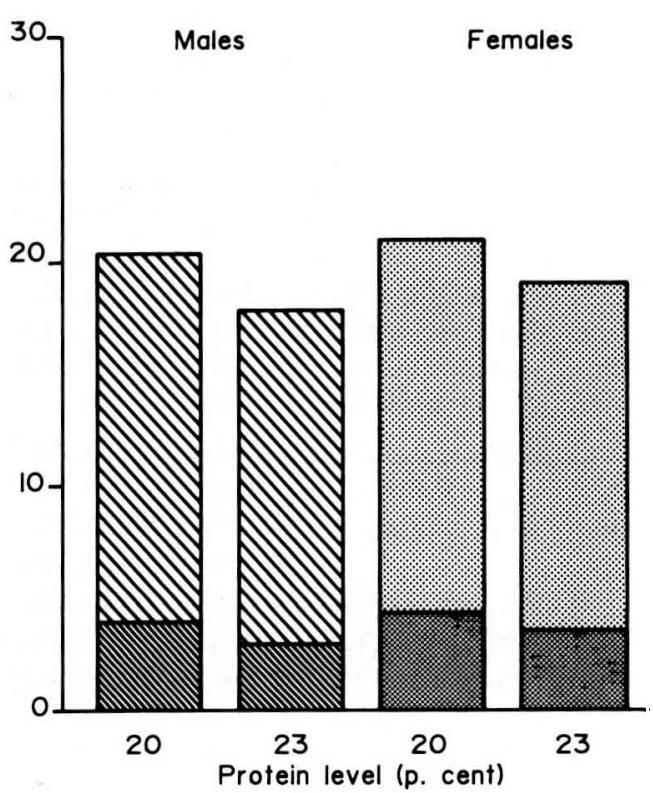

Fig 1. Influence of dietary protein level in 5-wkold broilers on: abdominal fatcarcass weight (\%): $\square$ males, $\%$ females; carcass lipids/ carcass weight (\%):

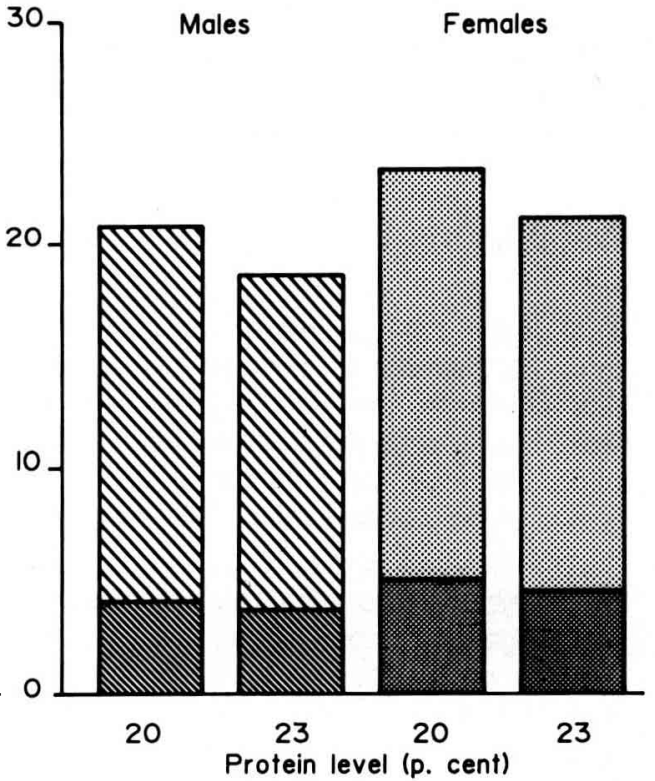

Fig 2 Influence of dietary protein level in 7-wkold broilers on: abdominal fat/carcass weight (\%): males, females; carcass lipids/ carcass weight (\%): decreased from 4.06 to $3.75 \%$ for males, and from 5.18 to $4.46 \%$ for females in birds fed on diets containing 20 or $23 \%$ CP respectively (fig 2 ). In contrast to abdominal fat, the reduction in carcass lipids ratio due to increased dietary protein level appeared to be greater in males than in females: 11.8 versus $7.7 \%$ for 7 -wk-old birds. Carcass lipids were reduced from 16.9 to $14.9 \%$ in males and from 18.1 to $16.7 \%$ in females as dietary protein level was increased from 20 to $23 \%$ respectively (fig 2).

Thus, it seemed that more lipids were deposited in the abdominal cavity of females than males for the same quantity of body fat. This was related to the significant effect of sex also observed for lipid ratio values both in the abdominal cavity and in eviscerated carcasses. Female birds were proportionally fatter than male birds. This effect did not appear when carcass lipids were expressed as absolute quantities.

Calculated relationships between carcass lipids without abdominal fat (CL, in g) and abdominal fat content $(A F$, in $g$ ) at 7 wk of age were expressed in the following equations:

for females fed 20\% CP: $C L=1.632 A F+$ $129.5(r=0.75)$

41830.81)

for males fed $20 \% C P: C L=1.117 A F+$ $190.21(r=0.56)$

or $23 \% \mathrm{CP}: \mathrm{CL}=2.052 \mathrm{AF}+126.12(r=$ $0.86)$. 
Correlation coefficients of all equations were highly significant $(P<0.001)$. At 5 wk of age, the correlation coefficients of such equations were not significant.

\section{DISCUSSION}

The growth rate appeared slightly lower than that commonly observed in the field; this could be explained by successive weighings and by the fast imposed on the birds. However, the feed conversion ratio was close to practical values.

The increase in dietary protein concentration from 20 to $23 \%$ did not improve weight gain of birds. This agrees with the findings of Summers and Leeson (1979), and Von Ehinger and Seeman (1982). Thus, a level of $20 \% \mathrm{CP}$ in diet appeared to be sufficient for maximal growth. However, feed efficiency can be improved by increased dietary protein concentration as observed by Jackson et al (1982) and Pesti and Fletcher (1984).

In agreement with previous observations (Pfaff and Austic, 1976; Summers and Leeson, 1979; Pesti and Fletcher, 1984) increasing dietary protein content reduced abdominal fat and lipid content of the carcass. However, the effect of protein on fatness reached a plateau: protein concentrations from 28-36\% did not affect either body lipid ratio, or feed conversion (Jackson et al, 1982).

The practical allowance of diets containing higher levels of protein than needed for practical growth cannot be recommended from an economical point of view. Instead of exposing chicks to a higher concentration of all amino acids, the supplementation of a single amino acid exceeding the level needed for optimal growth should be considered. Supplementation of essential amino acids such as methionine or lysine could play a specific role in the reduction of lipogenesis and fatness, as shown by Larbier and Leclercq (1980) and Uzu (1982), who used low protein diets.

The results indicated that the variation in CP from 20 to $23 \%$ decreased abdominal fat ratio more in females than in males at 7 wk of age (fig 2). However, the carcass lipid ratio was more reduced in males than in females, even though the variation in total lipids was similar in both sexes.

The influence of sex on body composition was significant. Females were always fatter than males (in agreement with Fisher, 1984; Nir et al, 1988) and this was associated with a greater adipocyte hypertrophy (Jones, 1986). Our results show that, at constant body fat, females displayed a higher deposition of fat in the abdominal cavity than males. But this was not observed in older animals, since females had a proportionally smaller abdominal fat pad than males (Hood and Pym, 1982; Hood, 1984).

The calculation of abdominal fat to total lipid ratio indicated that the distribution of lipids also varied with age. The deposition of lipids in the abdominal cavity was more pronounced in 7-wk-old chickens than in younger birds. Indeed, abdominal fat pad growth was more pronounced after other fat compartments had been deposited. Fisher (1984) noted that abdominal fat to total lipid ratio increased slowly after $40 \mathrm{~d}$ of age. By using linear regressions between the same variables, Scheele et al (1981) observed that the proportion of abdominal fat increased between $6-8 \mathrm{wk}$ of age in female birds. Furthermore, according to Nir et al (1988), the development of fat in various sites was not synchronous and depended on dietary composition.

The linear relationships calculated between carcass lipids and abdominal fat content were quite similar to those repor- 
ed in 1965 by Delpech and Ricard $(r=$ 0.82 ) for total lipids versus abdominal fat pad. According to Scheele et al (1981), a high correlation between abdominal fat and carcass fat does not mean that the main factors affecting total fat content are identical to those responsible for abdominal fat accumulation. Therefore, carcass lipid content cannot be precisely determined by abdominal fat content without considering the composition of the diet and presumably other factors.

\section{CONCLUSION}

In conclusion, it was found that feeding a high protein diet was accompanied by a reduction in fat deposition both in abdominal adipose tissue and in the other adipose compartments. The influence of excessive dietary protein on fat deposition may vary with sex and age. Further experiments with treatments providing a wider range of dietary protein level could supply further information on the role of dietary protein concentration in the distribution of body lipids and on lipid metabolism in broilers. The reduction in lipogenesis linked to the elevated protein concentration in the diet has often been observed, but most experiments have been carried out on one sex only (Yeh and Leveille, 1969; Bannister et al, 1983; Rosebrough et al, 1988). A possible interaction between lipogenic response, diet composition and sexual development should be also considered. Moreover, the increase in dietary protein is often compensated by a decrease in carbohydrate content. In studying the influence of dietary protein concentration on lipogenesis, the contribution of carbon chains of amino acids and carbohydrates should be considered.

\section{REFERENCES}

Bannister DW, N'Neill IE, Whitehead CC (1983) The effect of biotin deficiency and dietary protein content on lipogenesis, gluconeogenesis and related enzyme activities in chick liver. Br J Nutr 50, 291-302

Delpech P, Ricard FH (1965) Relation entre les dépôts adipeux viscéraux et les lipides corporels chez le poulet. Ann Zootech 14, 181-189

von Ehinger F, Seeman $G$ (1982) Einfluss von Futter, Alter und Geschlecht auf die Mastleistung und die Schlachtkörperqualität von Broilern verschiedener Herkunft. II. Mitteilung: Verfettungsgrad. Arch Geflügelkd 46, 177 . 188

Fisher C (1984) Fat deposition in broilers. In: Fats in Animal Nutrition (Wiseman J, ed) Butterworths, London, ch 21, 437-470

Guillaume J, Summers JD (1970) Influence of amino acid excess on energy utilization in the growing chick. Can J Anim Sci 50, 355-362

Hood RL (1984) Cellular and biochemical aspects of fat deposition in the broiler chicken. World's Poult Sci J 40, 160-169

Hood RL, Pym RAE (1982) Correlated responses for lipogenesis and adipose tissue cellularity in chickens selected for body weight gain, food consumption, and food conversion efficiency. Poult Sci 61, 122-127

Jackson S, Summers JD, Leeson S (1982) Effect of dietary protein and energy on broiler carcass composition and efficiency of nutrient utilization. Poult Sci 61, 2224-2231

Jones RL (1986) Nutritional influences on carcass composition in the broiler chicken. Proc Nutr Soc 45, 27-32

Larbier M, Leclercq B (1980) Le besoin en méthionine du poulet en finition. Ann Zootech $29,401-407$

Nir I, Nitsan Z, Keren-Zvi S (1988) Fat deposition in birds. In: Leanness of Domestic Birds. Genetic, Metabolic and Hormonal Aspects (Leclercq B, Whitehead CC, eds) Butterworths, London, ch 15, 141-174

Pesti GM, Fletcher DL (1984) The response of male broiler chickens to diets with various protein contents during the grower and the 
finisher phases. Br Poult Sci 25, 415-423

Pfaff FE, Austic RE (1976) Influence of diet on development of the abdominal fat pad in the pullet. J Nutr 106, 443-450

Rosebrough RW, McMurtry JP, Mitchell AD, Steele NC (1988) Chicken hepatic metabolism in vitro. Protein and energy relations in the broiler chicken. VI. Effect of dietary protein and energy restrictions on in vitro carbohydrate and lipid metabolism and metabolic hormone profiles. Comp Biochem Physio/ 90 (B), 311-316

Scheele CW, Van Schagen PJW, Ten Have HGM (1981) Abdominal and total fat content of three broiler strains at two ages affected by nutritional factors. Proc 5th Eur Symp:
Quality of Poultry Meat, Apeldoorn, NL, 397407

Summers JD, Leeson S (1979) Composition of poultry meat as affected by nutritional factors. Poult Sci 58, 536-542

Uzu G (1982) Limit of reduction of the protein level in broiler feeds. Poult Sci 61, 1557

Waldroup PW, Mabray CJ, Blackman JR, Slagter PJ, Short JD (1980) Influence of dietary energy and amino acid levels on abdominal fat pad. Poult Sci 59, 1669

Yeh YY, Leveille GA (1969) Effect of dietary protein on hepatic lipogenesis in the growing chick. J Nutr 98, 356-366 